Article

\title{
Varietal Threat Index for Monitoring Crop Diversity on Farms in Five Agro-Ecological Regions in India
}

\author{
Mohammad Ehsan Dulloo ${ }^{1, *(1)}$, Natalia Estrada Carmona ${ }^{2}$, Jai C. Rana ${ }^{3}$, Rashmi Yadav ${ }^{4}$ and Francesca Grazioli ${ }^{5}$ \\ 1 Bioversity International, 42 S. Sivananda Street, Rose-Hill 71368, Mauritius \\ 2 Bioversity International, Parc Scientifique Agropolis II, 1990 Bd de la Lironde, 34397 Montpellier, France; \\ n.e.carmona@cgiar.org \\ 3 Bioversity International, NASC Complex, Pusa, New Delhi 110012, India; j.rana@cgiar.org \\ 4 ICAR-National Bureau of Plant Genetic Resources, Pusa Campus, New Delhi 110012, India; \\ rashmigbp@gmail.com \\ 5 Bioversity International, 1 Via di San Domenico, 00153 Rome, Italy; F.grazioli@cgiar.org \\ * Correspondence: e.dulloo@cgiar.org
}

check for updates

Citation: Dulloo, M.E.; Estrada Carmona, N.; Rana, J.C.; Yadav, R.; Grazioli, F. Varietal Threat Index for Monitoring Crop Diversity on Farms in Five Agro-Ecological Regions in India. Diversity 2021, 13, 514. https: //doi.org/10.3390/d13110514

Academic Editor: Mario A. Pagnotta

Received: 15 September 2021

Accepted: 15 October 2021

Published: 22 October 2021

Publisher's Note: MDPI stays neutral with regard to jurisdictional claims in published maps and institutional affiliations.

Copyright: (C) 2021 by the authors. Licensee MDPI, Basel, Switzerland. This article is an open access article distributed under the terms and conditions of the Creative Commons Attribution (CC BY) license (https:// creativecommons.org/licenses/by/ $4.0 /)$.

\begin{abstract}
Our knowledge about the status of agrobiodiversity on farms is still very limited. While several studies to assess the crop genetic diversity on farms have been undertaken, there are no systematic documentation and monitoring practices for varietal diversity in space and time. Achievement of the agrobiodiversity Aichi Target 13, established under the Biodiversity Strategy Plan 2011-2020, have failed due to the lack of existing data on varietal diversity at country, regional and global levels. Here, we propose a method for calculating the Varietal Threat Index using the four-cell analysis (FCA) participatory methodology at different geographical scales to monitor changes in the varietal diversity on farms and to compare between areas. We tested the method with datasets collected from the UN-Environment GEF project implemented in India, in which data on crop and varietal diversity were collected across seven states in India, covering five agroecological regions. Results showed that landraces are still commonly grown in the study sites, especially in the central and western regions, and that more than $50 \%$ of landraces are considered threatened, suggesting that conservation interventions are required to prevent large-scale genetic erosion. A long-term monitoring framework for varietal diversity in India is proposed.
\end{abstract}

Keywords: landrace; Varietal Threat Index; monitoring varietal diversity; on-farm conservation; four-cell analysis; India

\section{Introduction}

Crop genetic resources for food and agriculture, and especially for varietal diversity on farms, are the basis for securing food and nutrition [1,2], for sustainable agriculture [3-5], for regulating and provisioning essential ecosystem services [6], as well as for coping with the impacts of climate change $[7,8]$. Varietal diversity, which is the diversity within crops, is defined as the extent of dissimilarity among a set of varieties [9] due to genetic differences. It includes both improved varieties and traditional crop varieties, also called landraces or farmer, local, primitive, heirloom, heritage, and indigenous varieties $[10,11]$. Traditional varieties (hereafter referred to as landraces) constitute a key biological resource often maintained by subsistence farmers and is cultivated for use values, indigenous beliefs, rituals, and, more importantly, for adaptive functions over space and time [5,12]. The recent state of the world report on biodiversity for food and agriculture concluded that genetic diversity within crop species is continuing to decline globally and threats to this diversity are increasing [13]. In fact, there are ample published evidence of the extent of genetic erosion in crop varieties on farms [6,14-16] but many of the studies reported are ad hoc assessments of genetic erosion at specific sites. Few long-term regional studies have attempted to assess varietal diversity of specific crops. For example, a long-term systematic 
monitoring framework for potato landraces in sentinel sites across its center of origin was developed and consisted of standardized procedures for measuring the total and relative varietal diversity at the farm level through networking and farmers participation [17]. At the European level, within the framework of the Farmer's Pride Horizon 2020 project, an attempt was made to map landrace diversity and identified 100 landrace hotspots to be part of a European network for both in situ conservation and sustainable use of plant genetic resources [18]. At a more global level, an assessment of on-farm varietal diversity data from 27 crop species from five continents were analyzed by measuring three elements of diversity, namely richness, evenness, and divergence [19]. It is widely recognized that there is no global systematic monitoring system in place for tracking crop genetic diversity on farms over time, as there are no global datasets at the varietal diversity level available $[13,15,20,21]$. It is further acknowledged that it is difficult to quantify the precise extent of genetic diversity given that a widely applicable indicator list for monitoring genetic diversity is yet to be developed [13]. Thus, monitoring crop genetic diversity on farms remains a global challenge and priority.

There are many global efforts led by the Food and Agriculture Organization of the United Nations (FAO), the Organization for Economic Co-operation and Development (OECD), and the Secretariat of the Convention on Biological Diversity (CBD) to develop targets and indicators for monitoring the global status of plant genetic resources for food and agriculture (PGRFA) [20]. Various sets of indicators have been proposed to monitor agricultural biodiversity, such as those developed by the FAO Commission on Genetic Resources for Food and Agriculture (CGRFA) on biodiversity for food and agriculture [22] and the indicators of the Aichi Target 13 developed for monitoring progress towards the Strategic Plan for Biodiversity 2011-2020 [23]. However, efforts to reach these targets have failed due to the lack of an internationally agreed upon set of indicators that satisfactorily measures the state of genetic diversity, especially for on-farm crop and varietal diversity, as well as due to a lack of existing data on genetic and varietal diversity $[13,20]$. Furthermore, a study developing an Agrobiodiversity Index for monitoring the status of agrobiodiversity in food systems also identified the lack of consistent, robust, and global data for several important components of agrobiodiversity, including on-farm varietal diversity [24].

Approaches for measuring crop in situ diversity can be based at the genetic and/or species level through molecular or participatory studies, respectively [20]. Despite the great advances in genetic analysis and data availability [25], analyzing allele frequencies within on-farm and wild populations for accurately monitoring genetic diversity worldwide is an ideal goal that will take time to become reality [26,27]. In the meantime, the use of proxy data, such as the variety names, can provide useful indications of the level of genetic diversity within crop species and at the on-farm level [12,28]. This type of assessment, grounded on local knowledge, can also consider the physical, social, and cultural factors important for the farming communities conserving and using these varieties [12,28].

There are a variety of participatory methods that are used to gather information on crop diversity in local communities, including rapid biodiversity assessment (PRA), household surveys, baseline surveys, community biodiversity registers, diversity fairs, focus group discussions (FGD), and the four-cell analysis (FCA), among others. The FCA is particularly interesting since it facilitates the understanding of distribution patterns of local crop diversity in a community and helps to identify common, unique, and rare local landraces for developing conservation plans [12]. The FCA methodology was first developed in Nepal to determine the risk of genetic diversity loss and the reasons why a species or variety is in a risk zone [12]. FCA differentiates between the varieties grown in a small or large cultivated area and by a small or large number of farmers [12] (Figure 1). This methodology has now been widely applied in different countries and in various ways to assess landrace diversity [29-32]. It has been used to study population structure, identify common and rare alleles, understand socio-economic reasons for conservation, and use values [29]. FCA has been also used as a decision tool for developing on-farm conservation actions [29-31] and assessing climate change impact on crop diversity [32]. 


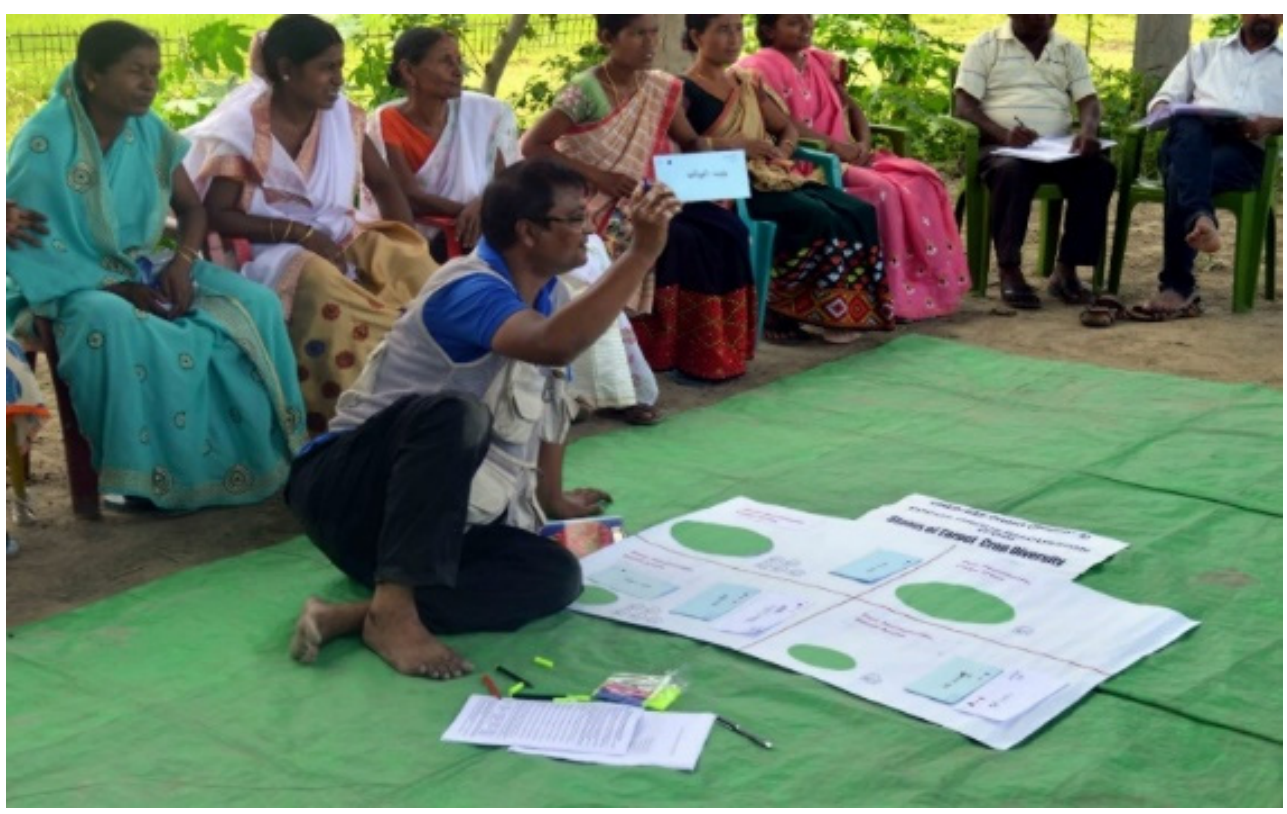

Figure 1. Focus group discussion using the four-cell analysis method at the Alengmora study site, India (Photo Credit: Rajib Sarma).

To date, despite the multiple methods and efforts, assessments to estimate the degree of threat of cultivated plant varieties are lacking [17,21]. The species level assessment through the IUCN Red List Index (RLI) [33,34] has been critical to monitor progress towards Biodiversity Aichi Target 12-prevention of the extinction of threatened species. The RLI index has also been applied to different species groups [35-37]. Applying the IUCN RLI to assess cultivated plant varieties threat status would be challenging since landrace names are unrecognized in the International Code of Nomenclature of Cultivated Plants or Botanical Nomenclature [38]. A new approach for red-listing cultivated plant species was in the past proposed based on the FCA methodology [21]. However, the approach lacks a quantitative measure to compare the extent of threat to the varietal diversity on farms across different regions. Hence, developing a threat index for varietal diversity would be very helpful in raising awareness of the status of agrobiodiversity and conservation actions.

In this paper, we present a methodology for calculating a threat index for crop varietal diversity (both improved varieties and landraces) on farms. We collected crop varietal diversity from 17 sites and five agroecological zones through the four-cell analysis (FCA) methodology in India. We adapted the RLI methodology to estimate the level of threat across crop varieties based on the FCA data. Our assessment, grounded on local knowledge and quantitative analysis, offers a robust and practical method for monitoring crop varieties and for differentiating the threat level by landraces and improved varieties. This method, relevant at the local scale and comparable at the national or global scale, can help prioritize conservation efforts for maintaining and using the agrobiodiversity vital for resilient, productive, and prosperous farms centered on securing food and nutrition.

\section{Methods}

\subsection{Survey Sites}

The study took place under the UN Environment/GEF project across the part of India in 17 study sites covering five contrasting agro-ecologies: Eastern Himalaya, Western Himalayan, Western Dry Region, Central Plateau and Hills, and Eastern Plateau and Hills. (Table 1). 
Table 1. Characteristics of the study sites.

\begin{tabular}{|c|c|}
\hline Agroecological Region/Features & $\begin{array}{l}\text { STUDY SITES NAMES } \\
\text { (Number of Villages) }\end{array}$ \\
\hline \multicolumn{2}{|l|}{ Eastern Himalaya } \\
\hline $\begin{array}{c}\text { Hot, humid, deep, loamy to clayey alluvium-derived soils, } \\
\text { available water capacity (AWC) is medium, LGP } 240-270 \text { days, } \\
\text { and } 50-80 \% \text { of area under forests. High temperatures combined } \\
\text { with heavy to very heavy rains. }\end{array}$ & $\begin{array}{l}\text { Dangdhora (7) } \\
\text { Alengmora (5) } \\
\text { Alami (11) }\end{array}$ \\
\hline \multicolumn{2}{|l|}{ Western Himalaya } \\
\hline $\begin{array}{c}\text { Soils shallow, loamy skeletal soils, cold to cool typic-arid, } \\
\text { available water capacity (AWC) is low, and length of growing } \\
\text { period (LGP) is } 60-90 \text { days. The Western Himalayan vegetation is } \\
\text { broadleaf and of two types: evergreen and deciduous } \\
\text { broadleaved forests. }\end{array}$ & $\begin{array}{c}\text { Bhilangana Valley (5) } \\
\text { Niti Valley (8) } \\
\text { Tarikhet (8) } \\
\text { Someshwar (8) } \\
\text { Ramana Nyay (12) } \\
\text { Gohar Valley (10) }\end{array}$ \\
\hline \multicolumn{2}{|l|}{ Eastern Plateau and Hills } \\
\hline $\begin{array}{c}\text { Moderately to gently sloping basin, hot, moist/dry, subhumid } \\
\text { transitional, deep loamy to clayey red and yellow soils, AWC } \\
\text { medium, and LGP 150-180 days. Vegetation is tropical moist } \\
\text { deciduous, tropical dry deciduous, and subtropical broad-leaved } \\
\text { hill forests. }\end{array}$ & $\begin{array}{c}\text { Ambikapur (11) } \\
\text { Korea (9) }\end{array}$ \\
\hline \multicolumn{2}{|l|}{ Central Plateau and Hills } \\
\hline $\begin{array}{l}\text { Hot, dry, subhumid, deep loamy to clayey mixed red and black } \\
\text { soils, AWC medium to high, and LGP 150-180 days. Vegetation of } \\
\text { Uttar Pradesh consists mostly of scrub. Forests are generally } \\
\text { concentrated in the southern uplands and predominantly consist } \\
\text { of tropical dry deciduous types. }\end{array}$ & $\begin{array}{c}\text { Karkeli (17) } \\
\text { Chitarkoot (19) }\end{array}$ \\
\hline \multicolumn{2}{|l|}{ Western Dry Region } \\
\hline $\begin{array}{l}\text { Hot typic-arid, deep, loamy desert soils (inclusion of saline } \\
\text { phase), AWC very low, and LGP 60-90 days. Forest types include } \\
\text { dry deciduous forest and thorn forest including scrub jungle. }\end{array}$ & $\begin{array}{l}\text { Dheerasar (6) } \\
\text { Didhu (8) } \\
\text { Damodara (5) } \\
\text { Osian (6) }\end{array}$ \\
\hline
\end{tabular}

\subsection{Focus Group Discussion}

In each study site, a focus group discussion (hereafter referred to as FGD) was held with farmers regardless of gender, ethnicity, and castes. They were identified in collaboration with local village leaders, local extension workers, and local non-governmental organizations based on the farmers' knowledge of the crops and varieties grown in the study sites. Prior to participation in the FGD, the participating farmers were informed about the scope of the study, the purpose of the data collection, the duration of their participation, and the voluntary nature of their participation. It was also made clear that there was no monetary or other compensation offered to the participants and that refusal to participate would incur no penalty. It was clearly stated at the beginning of each session that participants were free to drop out at any time. Verbal consent from each participating farmer was obtained. Data and information, including respondents' personal information, collected during the FGD, was secured by the Alliance of Bioversity International and CIAT, in compliance with its data protection regulations and policies.

\subsection{Four-Cell Analysis Method}

We used the four-cell analysis (FCA) [12] method to collect information on the crops and varieties grown in the study sites, in addition to their status and trends. The FCA is a rapid assessment and qualitative technique to assess the amount and distribution of crop diversity within farming communities and it facilitates the assessment of the inter 
or intra-specific diversity species (e.g., richness and evenness). Before listing species, we collectively discussed with farmers the threshold for defining 'few households (HH)' vs. 'many households' and 'small area' vs. 'large area'. Collectively, farmers agreed on 10\% as a good threshold for these groupings across sites. Then, each farmer listed the crop varieties that were grown in their household. Afterwards, each variety local name was placed in one of the four quadrants, indicating the spread and abundance of the variety across the study sites (Table 2, Figure 1).

Table 2. Four-cell analysis used for collecting varietal information across sites and quadrants (Q). Weight values are given in the parenthesis.

\begin{tabular}{|c|c|c|c|}
\hline & & \multicolumn{2}{|c|}{ Spread } \\
\hline & & Small Areas $(\leq \mathbf{1 0} \%)$ & Large Areas (>10\%) \\
\hline \multirow{2}{*}{ Abundance } & Few households $(\leq 10 \%)$ & $\begin{array}{l}\text { Q1-Threatened (TR) } \\
\text { (weight:4) }\end{array}$ & $\begin{array}{c}\text { Q2-Near Threatened (NT) } \\
\text { (weight:3) }\end{array}$ \\
\hline & $\begin{array}{l}\text { Many households } \\
\qquad(>10 \%)\end{array}$ & $\begin{array}{l}\text { Q3-Vulnerable (VU) } \\
\text { (weight:2) }\end{array}$ & $\begin{array}{l}\text { Q4-Least Concern (LC) } \\
\text { (weight:0) }\end{array}$ \\
\hline Lost varieties & Q5-Variet & $\begin{array}{r}\text { ley grew in the past } 10 \\
\text { (weight:5) }\end{array}$ & no longer grown \\
\hline
\end{tabular}

Farmers were also asked about the varieties they grew in the past 10 years that were no longer grown and the reason for its absence (i.e., lost varieties). For each listed variety, we also asked for information regarding major use, variety type (landrace or improved), and direction of change in area in the last 10 years (e.g., increasing or decreasing). After the crop and variety names were collected in the local/Hindi language, the botanical and English name of each species were determined and verified by the project research staff, who had expertise in botany, to avoid double counting. The crops and varieties were classified by improved varieties and landraces by the project research staff. Additionally, we classified each crop according to different food groups following the dietary diversity guidelines [39], namely concerning grains, pulses, condiments, dark green leafy vegetables, nuts and seeds, and oils or crop groups, specifically medicinal.

\subsection{Varietal Threat Index}

To calculate the Varietal Threat Index, we followed a modified methodology used to calculate the IUCN Red List Index [33] (See Supp. Material S1 for calculation). The varieties were grouped into four threat categories analogous to IUCN red list categories depending on the spread and abundance combination (Table 2.). Thus, varieties which were grown by

1. Few households and on small areas are considered as threatened (TR, Q1);

2. Few households but on large areas are considered as near threatened (NT, Q2);

3. Many households and on small areas are considered as vulnerable (VU, Q3);

4. Many households and on large areas are considered of least concern (LC; Q4); and

5. Lost varieties grew in the past 10 years but that are no longer grown (lost, Q5)

Each of the categories were given a weight with the 'Lost' category having a higher weight compared to the lower categories i.e., Lost-5; TR-4; NT-3; VU-2, and LC-0. A total threat score $(\mathrm{T})$ is then calculated by adding up the number of varieties in each category multiplied by its weight. A maximum threat score (M) was calculated per study site by adding up the number of varieties in each category per site and multiplying it with the maximum category weight (i.e., Lost 5). The Varietal Threat Index is then equal to the Maximum Threat Score (M) minus the Total Threat Score (T) and divided by the Maximum Threat Score (M). To make the score highest for the most threatened category, we then reverse the score by subtracting it from 1 . Thus:

$$
\text { Site Varietal Threat Index }=1-[(\mathrm{M}-\mathrm{T}) / \mathrm{M} \text {. }]
$$


The Varietal Threat Index would vary between 0 (where all varieties are of least concern) and 1 (where all varieties are 'Lost' from the site). In order to monitor trends in the diversity over time, the Varietal Threat Index would need to be calculated over regular period of time, depending on the resources available.

We calculated species richness and varietal evenness with the Vegan package in R [40,41]. Similarly, we used R for all other descriptive statics and used the 'ggstatsplot' package for pair-wise comparisons across agroecological zones with the non-parametric Games-Howell test adapted to unbalanced groups of variances and sample sizes [42]. For each species, we used the edible parts consumed in each village to allocate the corresponding food or crop group according to dietary diversity guidelines [39] or use (e.g., medicinal). We used the R package networkD3 to create the sanky diagram [43]. See Supplementary Materials S1 for the complete code and data used.

\section{Results}

\subsection{FGD Participation by Age and Gender}

In total, the FGD captured the knowledge of 578 farmers, covering seven Indian states and five agroecological zones (Figure 2A). On average, participants were 44 years old when the FGD took place, however, women tended to be slightly younger than the men (men average $=46$ years, $\mathrm{SE}=0.6$; women average $=42, \mathrm{SE}=0.7$; Figure $2 \mathrm{~B}$ ). Overall, the participation was balanced between the sex groups ( $58 \%$ men vs. $42 \%$ women), although women's participation was extremely low in states such as Madhya and Uttar Pradesh (Figure 2 C). About $10 \%$ of the female participants were head of households.
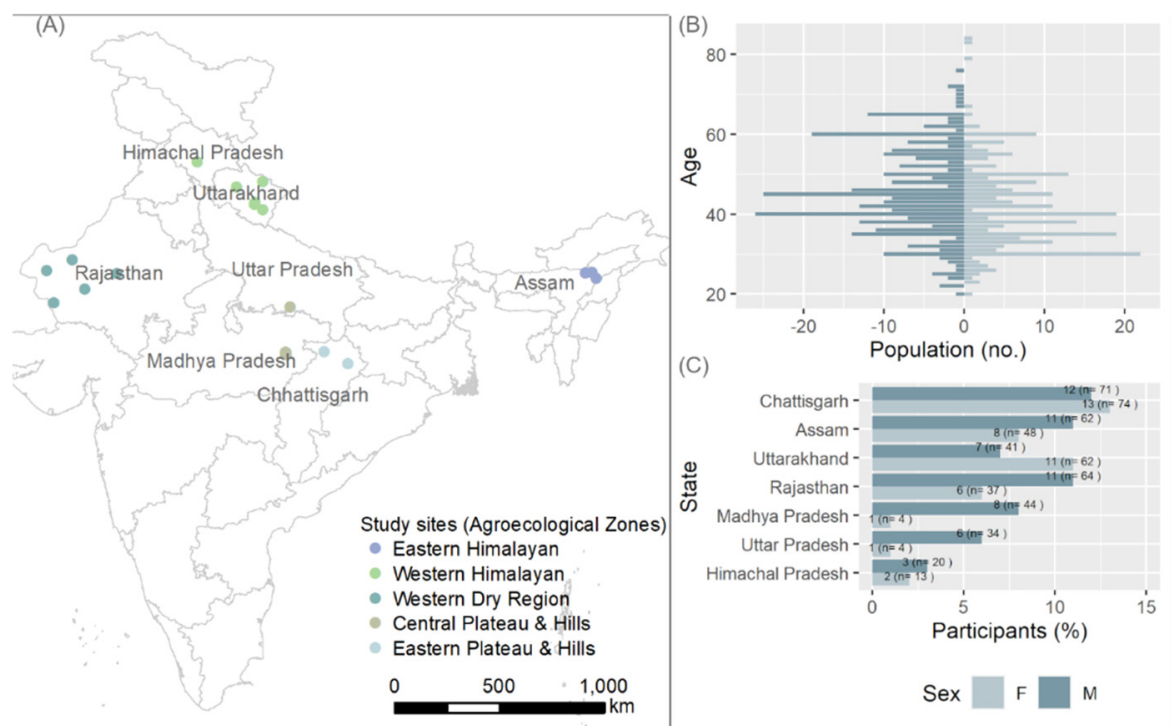

Figure 2. (A) Study site location across states and agroecological zones; (B) focus group discussion on population characterization across age and sex groups; and (C) states and sex groups (C). Numbers in $(\mathbf{C})$ represent the total percentage and the $n$ per state/sex group.

\subsection{Species Richness and Varieties Evenness}

The study revealed a total number of 38 crop species and 471 varieties, of which above $50 \%$ were rice varieties (Table 3 ). Crop richness was measured using the number of crops at the species level, whereas evenness accounted for the number of varieties within and across crop species. Our results indicate that the Eastern Himalayan is characterized by the lowest species richness, whereas both Eastern regions (Eastern Himalayan and Eastern Plateau and Hills) are characterized by the lowest varietal evenness due to the dominance of rice and rice varieties (164 and 47 Oryza sativa varieties, respectively; Figures 3 and 4). Central and western zones (particularly dry regions) reported higher species richness and 
significantly more evenly distributed varietal diversity, suggesting the presence of more varieties across crops (Figure 3).

Table 3. List of crops including the scientific name of cultivate species and the number of varieties identified in the study.

\begin{tabular}{|c|c|c|c|}
\hline Crop & Scientific Name of Cultivated Species & Number of Varieties & Percentage \\
\hline Grain Amaranth & Amaranthus hypochondriacus L. & 8 & 1.7 \\
\hline Groundnut & Arachis hypogaea L. & 2 & 0.4 \\
\hline Indian mustard & Brassica juncea L. & 15 & 3.2 \\
\hline Yellow mustard & Brassica rapa $\mathrm{L}$. & 4 & 0.8 \\
\hline Pigeon pea & Cajanus cajan (Linn.) Huth & 18 & 3.8 \\
\hline Chickpea & Cicer arietinum $\mathrm{L}$. & 7 & 1.5 \\
\hline Bitter cucumber & Citrullus colocynthis (L.) Schrad. & 1 & 0.2 \\
\hline Watermelon & Citrullus lanatus (Thunb.) Matsum. \& Nakai & 1 & 0.2 \\
\hline Cumin & Cuminum cyminum $L$. & 2 & 0.4 \\
\hline Cluster bean & Cyamopsis tetragonoloba (1.) Taub. & 11 & 2.3 \\
\hline Barnyard millet & Echinochloa esculenta (A.Braun) H.Scholz & 1 & 0.2 \\
\hline Finger millet & Eleusine coracana (L.) Gaertn. & 12 & 2.5 \\
\hline Common buckwheat & Fagopyrum esculentum Moench. & 2 & 0.4 \\
\hline Tartary buckwheat & Fagopyrum tataricum (L.) Gaertn. & 2 & 0.4 \\
\hline Soybean & Glycine max (L.) Merr. & 5 & 1.1 \\
\hline Niger & Guizotia abyssinica (L.f.) Cass. & 5 & 1.1 \\
\hline Barley & Hordeum vulgare L. & 1 & 0.2 \\
\hline Lentil & Lens culinaris Medik. & 3 & 0.6 \\
\hline Horse gram & Macrotyloma uniflorum (Lam.) Verdc. & 2 & 0.4 \\
\hline Rice & Oryza sativa $L$. & 259 & 55.0 \\
\hline Proso millet & Panicum miliaceum Walter & 1 & 0.2 \\
\hline Little millet & Panicum sumatrense Roth & 2 & 0.4 \\
\hline Kodo millet & Paspalum scrobiculatum L. & 1 & 0.2 \\
\hline Pearl millet & Pennisetum glaucum (L.) R. Br. & 9 & 1.9 \\
\hline Common Bean & Phaseolus vulgaris L. & 8 & 1.7 \\
\hline Pea & Pisum sativum L. & 2 & 0.4 \\
\hline Psyllium & Plantago ovata Forssk. & 1 & 0.2 \\
\hline Castor oil & Ricinus communis L. & 1 & 0.2 \\
\hline Sesame & Sesamum indicum $\mathrm{L}$. & 11 & 2.3 \\
\hline Foxtail Millet & Setaria italica (L.) P.Beauv. & 1 & 0.2 \\
\hline Sorghum & Sorghum bicolor (L.) Moench. & 1 & 0.2 \\
\hline Fenugreek & Trigonella foenum-graecum $\mathrm{L}$. & 1 & 0.2 \\
\hline Wheat & Triticum aestivum $\mathrm{L}$. & 23 & 4.9 \\
\hline Moth bean & Vigna aconitifolia (Jacq.) Maréchal & 7 & 1.5 \\
\hline Black gram & Vigna mungo (L.) Hepper & 16 & 3.4 \\
\hline Mung bean & Vigna radiata (L.) R. Wilczek & 15 & 3.2 \\
\hline Rice bean & Vigna umbellate (Thunb.) Ohwi \&H.Ohashi & 1 & 0.2 \\
\hline Maize & Zea_mays L. & 9 & 1.9 \\
\hline Total number & 38 & 471 & \\
\hline
\end{tabular}



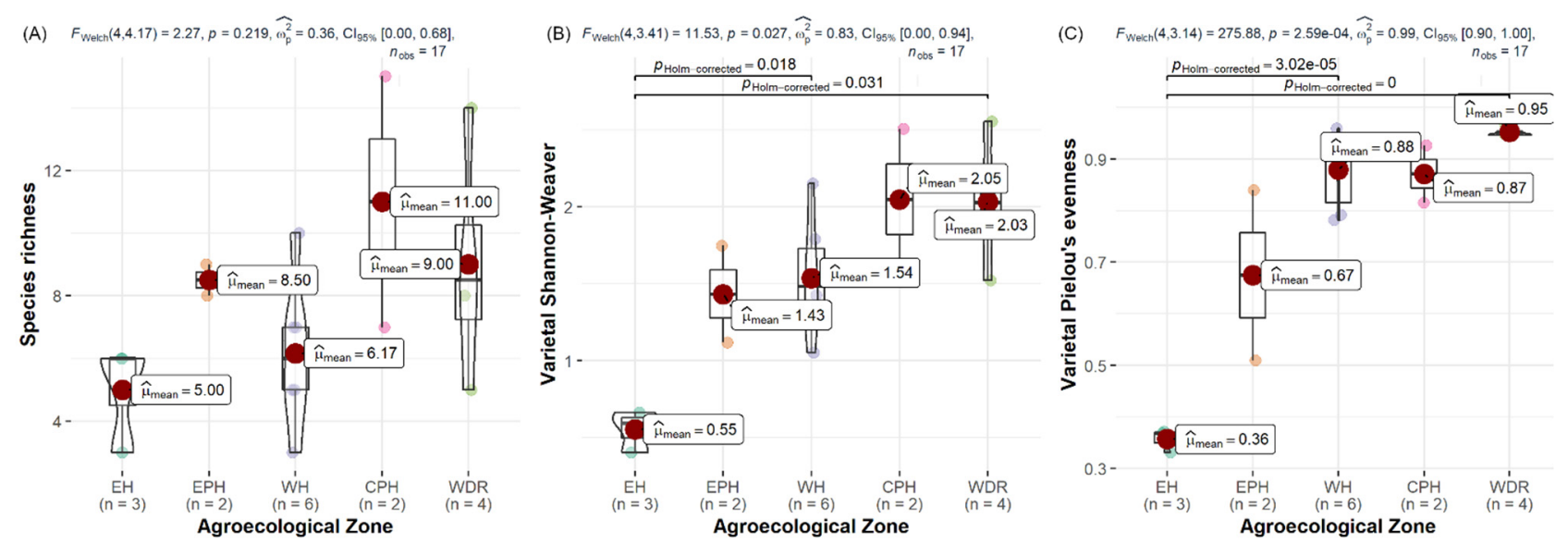

Figure 3. (A) Diversity indexes at the species (species richness); (B)varietal level (Shannon-Weaver); (C) varietal level (Pielou's). Abbreviations: EH, Eastern Himalayan; EPH, Eastern Plateau and Hills; WH, Western Himalayan; and CPH, Central Plateau and Hills; WDR: Western Dry Region. Significant pairwise comparisons of the Games-Howell test $p \leq 0.05$ are displayed.
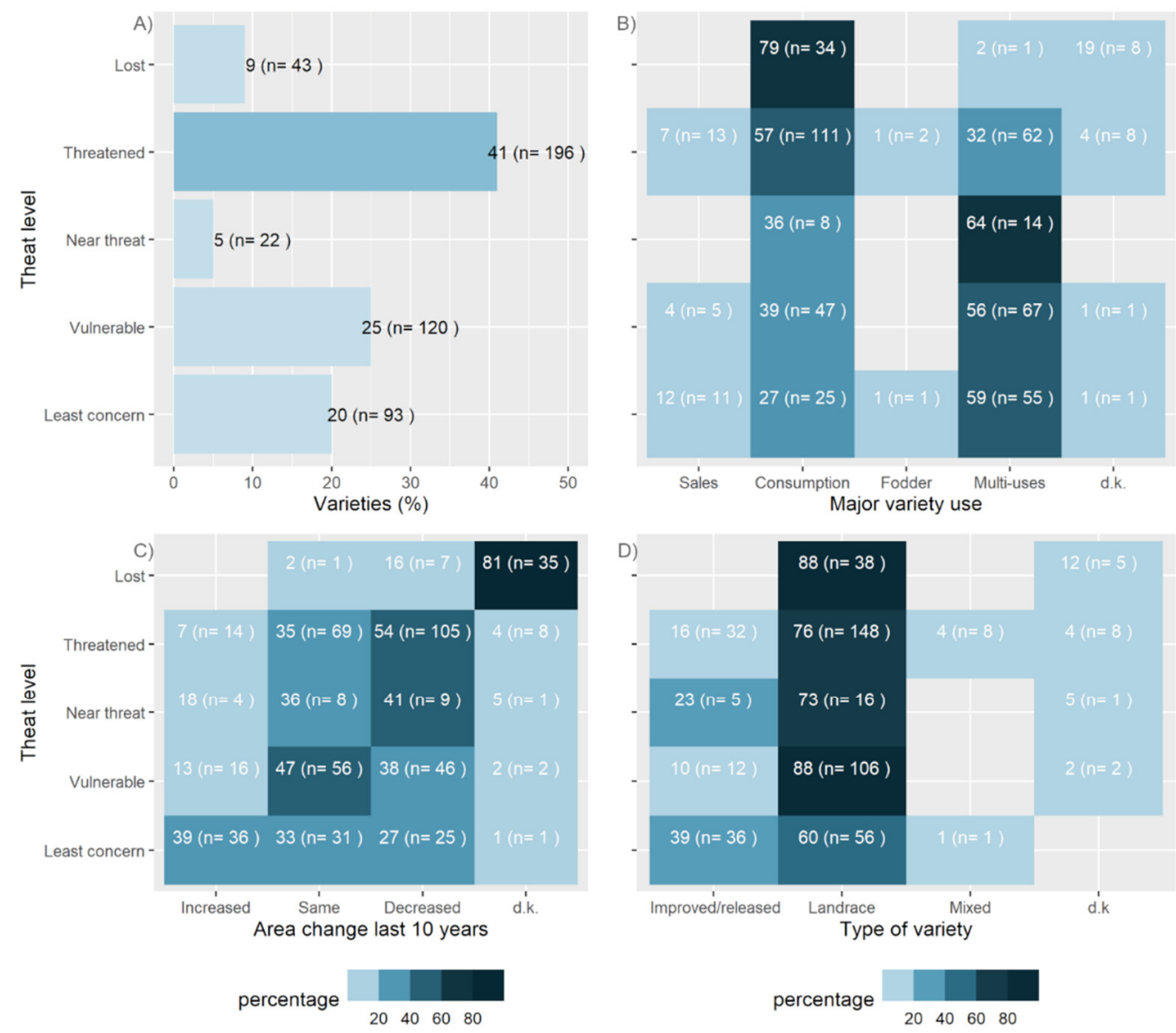

Figure 4. (A) Varieties distribution by threat level, (B) major use, (C) area change during the last ten years, and (D) variety type. Numbers indicate percentages and numbers of varieties' (in parenthesis) distribution at each threat level, which was at $100 \%$. Abbreviation: d.k., Do not Know.

\subsection{Varietal Threat Index: Threat Status and Trends}

More than half of the varieties listed across the study sites were under threatened or lost (50\%; Figure $4 \mathrm{~A})$ conditions. These threatened or lost varieties were mostly used for consumption (57\% and 79\% respectively) (Figure $4 \mathrm{~B})$. On the contrary, near threatened, vulnerable and least concern varieties were often used for multiple uses (sales, consump- 
tion, and fodder) (Figure 4B). A larger proportion of the threatened and, near threatened varieties decreased in area during the last 10 years whereas the area for a large proportion of the vulnerable varieties (47\%) remains stable according to farmers (Figure 4C). Varieties of least concern, predominantly improved or released varieties, were mostly increasing in area during the last 10 years and cultivated for multi-uses (Figure 4B-D). However, landraces are experiencing higher levels of threat with seventy six percent or above of landraces reported as vulnerable, near-threatened, threatened, and lost (Figure 4D).

Overall, landraces had a much larger threat index than the improved varieties, except in the Western Dry Region (Figure 5). The agroecological zones with the largest number of varieties and highest average of the Varietal Threat Index were the Western and Eastern Himalayan (0.539 and 0.588, respectively; Figure 5). The Central Plateau region also had an average Varietal Threat Index of 0.523; however, the number of varieties was half that of the Himalayan zones (Figure 5).

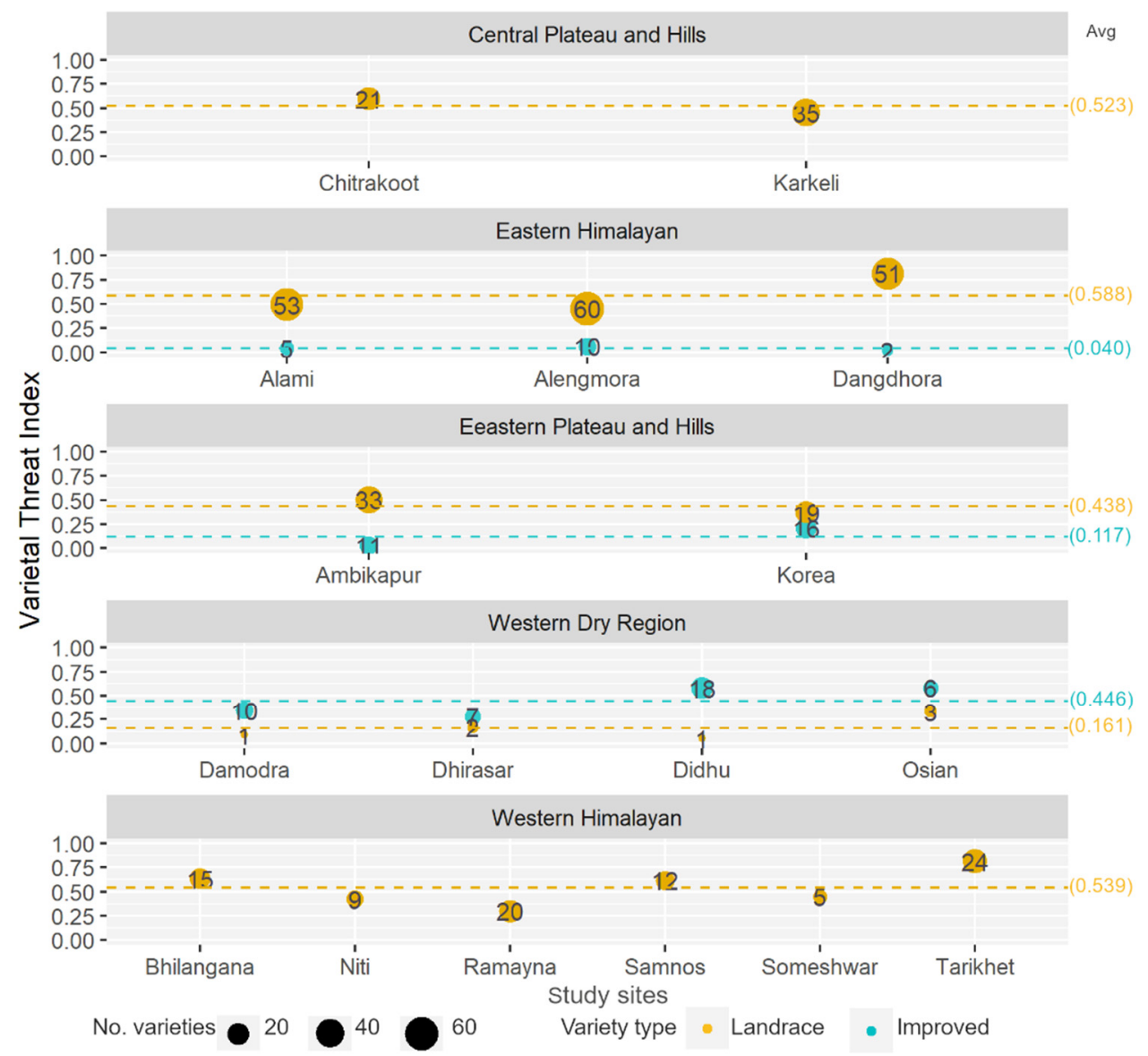

Figure 5. Varietal Risk Index at the agroecological and site level as well as by variety type. Numbers indicate the number of varieties. Average values per variety type are reported in parentheses on the right side of the figure.

All sites across the Western Dry Region reported the lowest threat level for landraces, although the number of reported varieties was extremely low (see, for example, Damodra, Didhu, or Osian; Figure 5), suggesting that the few listed landraces are doing relatively well. On the contrary, sites in Tarikhet and Dhangdhora in the Himalayan regions (western and eastern) reported a relatively large number of landraces with high threat index values (Figure 5). 


\subsection{Crop and Food Groups}

The Sanki diagram (Figure 6) shows the distribution and flows of landrace and improved varieties (left vertical green line) across the different food groups (grains, pulses, condiments, dark green leafy vegetables, nuts and seeds, oils, medicine, fruits, and vegetables; center green line) and agroecological zones (right vertical line). Among the varieties assessed, landraces dominated over improved varieties, grain-type varieties dominated over other food groups, and the Eastern Himalayan particularly reported the largest number of varieties, mostly of the grain type (i.e., rice). Landraces cover six food groups (grains, pulses, condiments, dark green leafy vegetables, nuts and seeds, and oils; Figure 6), whereas improved varieties cover nine food groups including condiment and seasoning, medicine, other fruits, and other vegetables, which are exclusively reported in the Western Dry Region (Figure 6). Overall, food group diversity remained low across the agroecological zones with cultivated varieties covering between four and five food groups, except for the dry region with eight food groups (left connections in Figure 6).

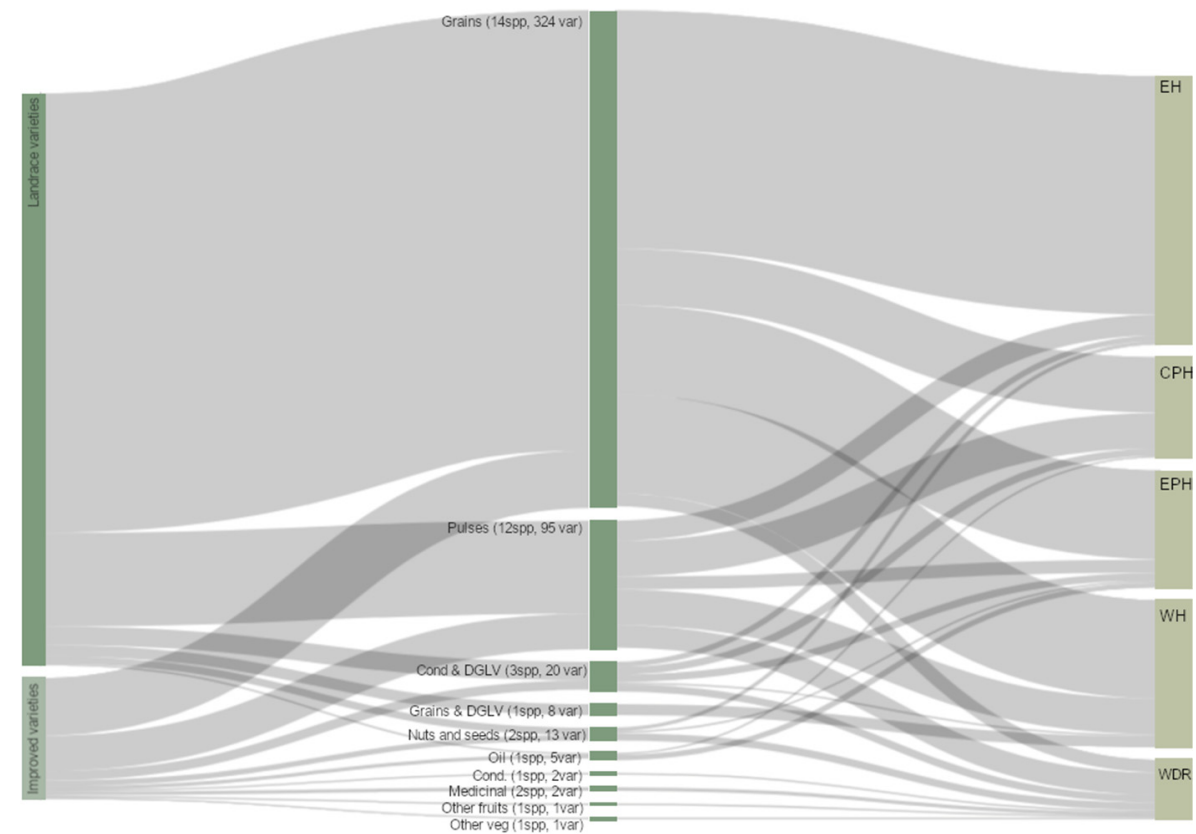

Figure 6. Sanki diagram showing the varietal flow and distribution between the type (landrace or improved/released) across food groups and the agroecological zones. Each food group includes the number of species (spp) and varieties (var) listed. Food groups include grains (e.g., wheat, barley, millets, maize, sorghum, and rice); pulses (e.g., gram, lentils, beans, and peas); condiments and DGLV, which are condiments, seasonings, and dark green leafy vegetables (e.g., mustard and fenugreek); grains and DGLV, which are grains and dark green leafy vegetables (e.g., amaranth); nuts and seeds (e.g. sesame and groundnut); oil (e.g., niger); medicine (e.g., Ricinus and Isabgol); other fruits (e.g., watermelon); and other vegetables (e.g., cucumber). Abbreviations: EH, Eastern Himalayan; EPH, Eastern Plateau and Hills; WH, Western Himalayan; CPH, Central Plateau and Hills; and WDR, Western Dry Region.

\section{Discussion}

\subsection{Varietal Diversity}

Crop and varietal diversity are critically important for food and nutrition security, as well as for the livelihoods of millions of people, particularly those living in marginal areas [44]. Measures for monitoring the crop varietal diversity on farms have been largely lacking [13] and represent a large gap in the monitoring frameworks for agrobiodiversity developed by UN organizations such the CBD, FAO, and SDG. In this study, we tested a methodology based on Four cell analysis - FCA [12] and adapted the IUCN Red List 
Index - RLI method [33,34] to document and monitor on-farm species/variety richness and evenness, as well as their level of threat on the farm, village and agroecological zone.

The simplicity of the method could help in closing the critical knowledge gap on onfarm varietal diversity and could contribute in monitoring it through time at local, regional, and even national levels. We showed that the FCA method and the novel Varietal Threat Index calculation, as presented here, enable the identification of varieties with varying threat levels, as well as the comparison across agroecological regions for developing locally relevant and national level policy recommendations for enhancing a more effective conservation and use of local agricultural biodiversity. It can help identify and highlight regions where landraces are declining and under greater threat (for example, Western and Eastern Himalayan, as shown in this study), and can guide policy makers to take remedial actions for reversing the genetic erosion trend in the vulnerable sites, particularly for crops and varieties that are important for consumption, nutrition, and other uses. The study clearly showed that there is still a great diversity of landrace that local farmers cultivate and use for multiple purposes. Nonetheless, varietal diversity varied across states depending on different agroecological regions Despite some areas being dominated by rice varieties (e.g., eastern regions), we also found other cultivated crops. For example, in the Eastern Himalayan region, in the state of Assam, 164 varieties of rice were grown by farmers, but they also cultivate a few other crops such as mung bean, mustard, and pigeon pea, with only few varieties ranging from one to four. Despite the large landrace and crop diversity, our results indicate that most of this diversity is disappearing during the last 10 years according to farmers' knowledge.

Despite the robustness of the method proposed here, there are some challenges and improvements required. The first challenge of using FCA methodology across sites with a high linguistic diversity concerns the verification and validation of the local names provided by communities. This problem has been highlighted before and it is well known that the naming of landraces may vary between crops and cultures in both space and time [28]. However, some studies have shown that the traditional way in naming varieties can be remarkably reliable and crucial to the subsistence of the farming community $[19,45]$. In our study, this issue was considered and the naming of landraces of same crops across the different sites were scrutinized and verified by local research staff to ensure that the names were indeed unique and consistent across the local communities from different villages and regions. However, the methodology can be more robust if FCA is complemented with ethnobotanical studies or varietal data collection in terms of conservation to triangulate, verify, and document the various common names used across regions for the same species.

Another caveat in the FCA methodology relates the definition of 'few' and 'many' households and "small" and "large" areas. In the current study, the threshold level was decided during the FGD with the farmers themselves and there was a general agreement for using $10 \%$ as a threshold that divides few vs. many farmers and small vs. large areas. Our approach of collectively selecting the threshold, rather than imposing it, helped to have a better and more collective sense of the selected threshold value, potentially leading to better results. Nonetheless, some further research would be required to empirically confirm the accuracy of the selected threshold and to investigate the variability across thresholds selected in different contexts (e.g., different types of crops and areas required for their cultivation), as well as the implications on the results.

Finally, the success of the FGD in capturing varietal diversity depends on the level of engagement and participation of the farmers, regardless of the sex, cast, and socioeconomic and marital status. In some cases, women and men tended to use different parts of the landscapes and cultivated or managed plants for different purposes (e.g., household consumption or income) [46-48]. In our study, women's participation was low in some regions due to their time limitation due to childcaring and other home-caring activities, indicating that some crops important for household consumption or other uses may be particularly underrepresented in these areas. Hence, ensuring that the FGD are inclusive and offer options for baby-sitting or child-caring could help increase women's participation. 
Capturing gendered knowledge on crop varieties is critical for properly monitoring the multi-functionality of farms and landscapes, and more importantly for developing varietal conservation efforts that are gender-inclusive [48-50].

\subsection{Varietal Threat Index}

The Varietal Threat Index revealed that in all the agroecological zones, apart from the Western Dry Region, farmer varieties were more threatened than improved, which could be related to the promotion of improved varieties and easy availability of their seeds by farmers to grow them over local varieties [51,52]. The participants from the Western Dry Region mentioned much less crop and landrace diversity than in other regions but did mention more food groups unique to the region, such as condiments, medicine, and other fruits (watermelon) and vegetables (cucumber). Both cucumber and watermelon were improved varieties well adapted to dry environments and poorly developed friable soils $[53,54]$. However, maintaining the few listed landraces that have a low threat risk is critical for future options, since plants in drier environments tend to have special adaptive capacities to survive the water stress in such extreme environments.

\subsection{Monitoring Trends in Varietal Diversity}

Given that we have no baseline data from the study sites to compare the results of the surveys described above, participants were asked about the changes in the areas where varieties have been grown over the last 10 years. This allowed us to have some idea about the trends in varietal diversity in the study sites. In general, we noted that the varieties of LC status are increasing in areas presumably because they are the more popular varieties. As we move from LC to the increasing threat categories (VU, NT, and TR), there is a reverse trend in area change, which, in the long run, will certainly be on track towards lost from the production system. The displacement by yield improved varieties will lead to genetic erosion and will reduce future options for sustaining agriculture. This is despite the fact that the market value of landraces is high as compared to improved varieties due to their local preference, nutritional superiority, and the existence of incentives provided by the Government of India to promote and incentivize cultivation of landraces through the Plant Genome Savior Community Award provided under the provision of section 45 of the Protection of Plant Varieties and Farmers' Rights Act, 2001. Our results confirm the trends in genetic erosion that have been reviewed in many crops and countries [6,14,15], which generally provides clear evidence of the loss of genetic diversity on farms. However, there is a lack of hard baseline data against which changes in the genetic diversity of agrobiodiversity can be properly monitored, as recognized in recent State of the World reports on Biodiversity for Food and Agriculture [13,17]. This lack of information on on-farm and in situ diversity, as well as regarding its availability in public domains, severely limits the ability to properly track changes in agrobiodiversity over time. The Agrobiodiversity Index being developed by the Alliance of Bioversity International and CIAT [24] illustrates this issue, as the indicator for varietal diversity on farms cannot be applied as there exists no publicly available information at the global nor country level, except for data that are contained in ex situ collections and that are publicly available at the global level, such as Genesys [55]. Thus, the difficulty concerns how we can capture the on-farm varietal diversity from the field and make this information available for the systematic monitoring of on-farm varietal diversity to ensure that decision and policymakers take appropriate actions for the conservation of agrobiodiversity on farms and with farmers. To this end, we require a methodology that can systematically document what varieties farmers are growing. We posit that the FCA methodology, which has been used in this study and in other countries [29,31], has potential if adopted by local authorities and organized into a network for the regular monitoring of diversity over time, preferably every 5 years to detect any changes in diversity, which is aligned with the reporting process of the CBD National Biodiversity Action Plan. For example, in India, the local government system of "Panchayats", which is organized at the village level and up to the district and 
state levels, could provide a framework for monitoring varietal diversity on farms and could help to inform others on diversity from the village level to district, state, and national levels. The Panchayat or other similar governance systems also exist in other countries (e.g., Nepal and Bangladesh), which serve similar functions.

As mentioned earlier in the introduction, in other continents such as in Latin America, systematic monitoring of varietal diversity has also been developed based on the identification of hotspot areas containing high concentrations of distinct landraces [17]. It is also important that the results of the FCA are documented in agrobiodiversity-related public or global databasessystems or repositories that can be maintained and that can serve as baseline information for monitoring purposes. Such information systems or repositories should be readily accessible and available, while sensitive data and information should be properly managed to ensure compliance with general privacy data protection regulations and to protect any indigenous knowledge from being exploited for commercial gains.

\section{Conclusions}

The study has presented a snapshot of the varietal diversity across seven states and different agroecological zones in India. The novel method of using the FCA methodology for calculating a Varietal Threat Index is critical for the baseline assessing and monitoring of genetic erosion. This study has revealed that there is still a significant diversity of landraces grown, especially in the central and western regions, and that more than 50\% of farmers' varieties are threatened. We recommend the promotion and adoption of the proposed methodology among the local authorities in "Panchayats" in India and elsewhere to ensure that it can be applied at wider scale and lead to the development of a monitoring framework for varietal diversity at the village, state, and national level. This will make a significant contribution to the global monitoring of agrobiodiversity through the FAO Global Plan of Action and the CBD post-2020 Global Biodiversity framework.

Supplementary Materials: The following are available online at https:/ /www.mdpi.com/article/10 .3390/d13110514/s1, Script S1: Varietal_Threat_script.html.

Author Contributions: M.E.D. and J.C.R. conceived the paper; J.C.R. and R.Y. carried out the field surveys and compiled the data; M.E.D., N.E.C., R.Y. and F.G. carried out the data analysis; M.E.D. developed the Varietal Threat Index methodology; M.E.D., N.E.C., J.C.R. and F.G. contributed to writing the manuscript. All authors have read and agreed to the published version of the manuscript.

Funding: The field work for this study was funded by the United Nations Environment/Global Environmental Fund as part of the project entitled "Mainstreaming agricultural biodiversity conservation and utilization in the agricultural sector to ensure ecosystem services and reduce vulnerability". E.D., F.G., and N.E.C. were funded under the Agrobiodiversity Index project supported by the Government of Italy. N.E.C. was funded by ICAR and the CGAIR cross research program Water, Land, and Ecosystems (WLE).

Institutional Review Board Statement: This study did not go through an IRB approval process but the ethical procedures followed have been explained in the methodology section.

Informed Consent Statement: Informed consent was obtained from all subjects involved in the study, as described in Section 2.2 of the paper.

Data Availability Statement: All data collected are contained within the Alliance of Bioversity International and CIAT DATAVERSE repository. Data has been anonymized so as to be compliant with GDPR data protection regulations.

Acknowledgments: This research study was conducted with funding provided under the UN Environment implanted GEF project 'Mainstreaming agricultural biodiversity conservation and utilization in agricultural sector to ensure ecosystem services and reduce vulnerability in India (Project Code: A 1265)', which was executed jointly by the Alliance of Bioversity International and CIAT, and the Indian Council of Agricultural Research (ICAR). The authors thank the farmer households for effectively interacting and sharing their valuable information on traditional farming and native food system across different agro-ecoregions. We extend our special thanks to the project 
partners at the different study sites for facilitating the process and participation in the FGD meetings during the surveys. Last but not least, we thank the project staff, specifically Sonal Dsouza and Abhishek Saxena who helped in the project logistics and compilation of data.

Conflicts of Interest: The authors declare no conflict of interest.

\section{References}

1. De Haan, S.; Burgos, G.; Liria, R.; Rodriguez, F.; Creed-Kanashiro, H.M.; Bonierbale, M. The nutritional contribution of potato varietal diversity in Andean food systems: A case study. Am. J. Potato Res. 2019, 96, 151-163. [CrossRef]

2. Gotor, E.; Usman, M.A.; Occelli, M.; Fantahun, B.; Fadda, C.; Kidane, Y.G.; Mengistu, D.; Kiros, A.Y.; Mohammed, J.N.; Assefa, M.; et al. Wheat varietal diversification increases Ethiopian smallholders' food security: Evidence from a participatory development initiative. Sustainability 2021, 13, 1029. [CrossRef]

3. FAO. The Second Report on the State of the World's Animal Genetic Resources for Food and Agriculture; Food and Agriculture Organization of the United Nations: Rome, Italy, 2010. [CrossRef]

4. Bioversity International. Mainstreaming Agrobiodiversity in Sustainable Food Systems: Scientific Foundations for an Agrobiodiversity Index; Bioversity International: Rome, Italy, 2017.

5. Bisht, I.S.; Rana, J.C.; Yadav, R.; Ahlawat, S.P. Mainstreaming agricultural biodiversity in traditional production landscapes for sustainable development: The Indian Scenario. Sustainability 2020, 12, 10690. [CrossRef]

6. Gatto, M.; De Haan, S.; Laborte, A.; Bonierbale, M.; Labarta, R.; Hareau, G. Trends in varietal diversity of main staple crops in Asia and Africa and implications for sustainable food systems. Front. Sustain. Food Syst. 2021, 5, 12. [CrossRef]

7. FAO. Coping with Climate Change: The Roles of Genetic Resources for Food and Agriculture; Food and Agriculture Organization of the United Nations, Ed.; FAO: Rome, Italy, 2015.

8. Belem, M.; Bazile, D.; Coulibaly, H. Simulating the impacts of climate variability and change on crop varietal diversity in Mali (West-Africa) using agent-based modeling approach. J. Artif. Soc. Soc. Simul. 2018, 21, 8. [CrossRef]

9. Widawsky, D.; Rozelle, S. Varietal diversity and yield variability in chinese rice production. In Farmers Gene Banks and Crop Breeding: Economic Analyses of Diversity in Wheat Maize and Rice; Smale, M., Ed.; Springer: Dordrecht, The Netherlands, 1998. [CrossRef]

10. Negri, V.; Maxted, N.; Vetelainen, M. European landraces: On-farm conservation, management and use. In European Landraces: On Farm Conservation, Management and Use; Vetelainen, M., Negri, V., Maxted, N., Eds.; Bioversity International: Rome, Italy, 2009.

11. Juventia, S.D.; Jones, S.K.; Laporte, M.-A.; Remans, R.; Villani, C.; Estrada-Carmona, N. Text mining national commitments towards agrobiodiversity conservation and use. Sustainability 2020, 12, 715. [CrossRef]

12. Sthapit, B.R.; Rana, R.B.; Subedi, A.; Gyawali, S.; Bajracharya, J.; Chaudhary, P.; Joshi, B.K.; Sthapit, S.; Joshi, K.D.; Upadhyay, M.P. Participatory four cell analysis (FCA) for local crop diversity. In Good Practices: On-Farm Management of Agricultural Biodiversity in Nepal; NARC, LI-BIRD, IPGRI and IDRC, Nepal: Nagarkot, Nepal, 2006; Volume 260.

13. FAO. The State of the World's Biodiversity for Food and Agriculture; Fao Commission on Genetic Resources for Food and Agriculture Assessments: Rome, Italy, 2019.

14. Dulloo, M.E.; Thormann, I.; Drucker, A.G. 39 What do we have to lose? Monitoring crop genetic diversity. In Enhancing Crop Genepool Use: Capturing Wild Relative and Landrace Diversity for Crop Improvement; Maxted, N., Dulloo, M.E., Lloyd, B.F., Eds.; CABI: Wallingford, UK, 2016; p. 421.

15. Thormann, I.; Engels, J.M.M. Genetic diversity and erosion-A global perspective. In Genetic Diversity and Erosion in Plants. Sustainable Development and Biodiversity; Ahuja, M., Jain, S., Eds.; Springer: Berlin/Heidelberg, Germany, 2015. [CrossRef]

16. Bisht, I.S.; Rana, J.C.; Pal Ahlawat, S. The future of smallholder farming in India: Some sustainability considerations. Sustainability 2020, 12, 3751. [CrossRef]

17. De Haan, S.; Polreich, S.; Rodriguez, F.; Juarez, H.; Ccanto, R.; Alvarez, C.; Otondo, A.; Sainz, H.; Venegas, C.; Kalazich, J. A Long-Term Systematic Monitoring Framework for On-Farm Conserved Potato Landrace Diversity. Enhancing Crop Genepool Use Ca Capturing Wild Relative and Landrace Diversity for Crop Improvement; Maxted, N., Dulloo, M.E., Lloyd, B.F., Eds.; Cabi International: Wallingford, UK, 2016; pp. 289-296.

18. Raggi, L.; Pacicco, C.L.; Barata, A.M.; Bartha, B.; Heinonen, M.; Maxted, N.; Ralli, P.; Negri, V. Landrace Hotspots Identification in Europe. Farmer's Pride: Networking, Partnerships and Tools to Enhance in Situ Conservation of European Plant Genetic Resources. 2020. Available online: https://more.bham.ac.uk/farmerspride/wpcontent/uploads/sites/19/2020/10/D1.4 _Landrace_hotspots_identification_in_Europe.pdf (accessed on 10 August 2021).

19. Jarvis, D.I.; Brown, A.H.D.; Cuong, P.H.; Collado-Panduro, L.; Latournerie-Moreno, L.; Gyawali, S.; Tanto, T.; Sawadogo, M.; Mar, I.; Sadiki, M. A global perspective of the richness and evenness of traditional crop-variety diversity maintained by farming communities. Proc. Natl. Acad. Sci. USA 2008, 105, 5326-5331. [CrossRef]

20. Dulloo, M.E.; Bissessur, P.; Rana, J. Monitoring plant genetic resources for food and agriculture. In Plant Genetic Resources: A Review of Current Research and Future Needs; Dulloo, M.E., Ed.; Burleigh Dodds Science Publishing: Cambridge, UK, 2021; pp. 55-80.

21. Padulosi, S.; Bergamini, N.; Lawrence, T. On-Farm Conservation of Neglected and Underutilized Species: Status, Trends and Novel Approaches to Cope with Climate Change: Proceedings of an International Conference, Frankfurt, Germany, 14-16 June 2011; Bioversity International: Rome, Italy, 2012. 
22. FAO. International Targets and Indicators for Biodiversity for Food and Agriculture; Commission on Genetic resources for Food and Agriculture, Thirteenth Regular Session. 2011, CGRFA 13/11/18; FAO: Rome, Italy, 2011.

23. CBD. AICHI Biodiversity Target. Available online: https://www.cbd.int/sp/targets/ (accessed on 16 June 2021).

24. Jones, S.; Estrada-Carmona, N.; Juventia, S.D.; Dulloo, M.; Laporte, M.; Villani, C.; Remans, R. An Agrobiodiversity Index scores show agrobiodiversity is underutilized in national Food System Policy. Nat. Food 2021, 2, 712-723. [CrossRef]

25. Hoban, S.; Bruford, M.; Jackson, J.D.; Lopes-Fernandes, M.; Heuertz, M.; Hohenlohe, P.A.; Paz-Vinas, I.; Sjögren-Gulve, P.; Segelbacher, G.; Vernesi, C.; et al. Genetic diversity targets and indicators in the CBD post-2020 global biodiversity framework must be improved. Biol. Conserv. 2020, 248, 108654. [CrossRef]

26. Bruford, M.W.; Davies, N.; Dulloo, M.E.; Faith, D.P.; Walters, M. Monitoring changes in genetic diversity. In The GEO Handbook on Biodiversity Observation Networks; Walters, M., Scholes, R.J., Eds.; Springer International Publishing: Cham, Switzerland, 2017. [CrossRef]

27. Mondini, L.; Noorani, A.; Pagnotta, M. Assessing plant genetic diversity by molecular tools. Diversity 2009, 1, 19-35. [CrossRef]

28. Brown, A.H.D.; Hodgkin, T. 2. Measuring, managing, and maintaining crop genetic diversity on farm. In Managing Biodiversity in Agricultural Ecosystems; Jarvis, D.I., Padoch, C., Cooper, H.D., Eds.; Columbia University Press: New York, NY, USA, 2007; pp. 13-33.

29. Rana, R.B.; Sthapit, B.R.; Garforth, C.; Subedi, A.; Jarvis, D.I. Four-cell analysis as a decision-making tool for conservation of agrobiodiversity on-farm. In On-Farm Conservation of Agricultural Biodiversity in Nepal; Sthapit, B.R., Upadhyay, M.P., Shrestha, P.K., Jarvis, D.I., Eds.; Bioversity International Nepal: Nagarkot, Nepal, 2005; Volume 2, pp. 15-24.

30. Vernooy, R.; Sthapit, B.; Tjikana, T.T.; Dibiloane, A.; Maluleke, N.; Mukoma, T. Embracing Diversity: Inputs for a Strategy to Support Community Seedbanks in South Africa's Smallholder Farming Areas: Report of Field Visits to Limpopo and Eastern Cape; Bioversity International: Rome, Italy; Department of Agriculture, Forestry and Fisheries: Pretoria, South Africa, 2013.

31. Khanal, S.; Dangol, D.R. Assessment of landraces of rice and maize by four cell analysis at Sorabhag, V.D.C. Marang, Nepal. Himal. Biodivers. 2016, 4, 49-52.

32. Ghimire, Y.N.; Rana, R.B.; Ale, S.; Poudel, I.; Tamang, B.B. Use of agrobiodiversity and crop management practices for climate change adaptation in high hill agriculture of Nepal. J. Agric. Environ. 2017, 18, 6-14. [CrossRef]

33. Butchart, S.H.M.; Resit Akçakaya, H.; Chanson, J.; Baillie, J.E.M.; Collen, B.; Quader, S.; Turner, W.R.; Amin, R.; Stuart, S.N.; Hilton-Taylor, C. Improvements to the red list index. PLoS ONE 2007, 2, e140. [CrossRef]

34. IUCN. IUCN Red List Categories and Criteria: Version 3.1; IUCN: Gland, Switzerland, 2012.

35. Butchart, S.H.M.; Stattersfield, A.J.; Bennun, L.A.; Shutes, S.M.; Akçakaya, H.R.; Baillie, J.E.M.; Stuart, S.N.; Hilton-Taylor, C.; Mace, G.M.; Reid, W.V. Measuring global trends in the status of biodiversity: Red list indices for birds. PLoS Biol. 2004,2 , e383. [CrossRef]

36. Marler, P.N.; Marler, T.E. An assessment of red list data for the cycadales. Trop. Conserv. Sci. 2015, 8, 1114-1125. [CrossRef]

37. Lewis, O.T.; Senior, M.J.M. Assessing conservation status and trends for the world's butterflies: The sampled red list index approach. J. Insect Conserv. 2011, 15, 121-128. [CrossRef]

38. Hammer, K.; Hammer-Spahillari, M.; Khoshbakht, K. Red lists for cultivated species: Experiences with the IUCN list of threatened plants. In On Farm Conservation of Neglected and Underutilized Species: Status, Trends and Novel Approaches to Cope with Climate Change: Proceedings of an International Conference, Frankfurt, Germany 14-16 June 2011; Padulosi, S., Bergamini, N., Lawrence, T., Eds.; Bioversity International: Rome, Italy, 2012; pp. 127-136.

39. Davis, U. Minimum Dietary Diversity for Women - A Guide to Measurement; FAO: Rome, Italy, 2016.

40. Oksanen, J.; Blanchet, F.; Friendly, M.; Kindt, R.; Legendre, P.; McGlinn, D.; Peter, R.; Minchin, P.R.; O'hara, R.B.; Simpson, G.L.; et al. Vegan: Community Ecology Package. R Package Version 2.5-7. Available online: https://CRAN.R-Project.Org/Package= vegan (accessed on 25 August 2021).

41. R Core Team. R: A Language and Environment for Statistical Computing; R Foundation for Statistical Computing: Vienna, Austria, 2021; Available online: https: / / www.r-project.org/ (accessed on 25 August 2021).

42. Patil, I. Visualizations with statistical details: The 'ggstatsplot' approach. J. Open Source Softw. 2021, 6, 3167. [CrossRef]

43. Allaire, J.J.; Gandrud, C.; Russell, K.; Yetman, C.J. NetworkD3: D3 javascript network graphs from R. R Package 2017 Version 0.4, 2014.

44. Herrero, M.; Thornton, P.K.; Power, B.; Bogard, J.R.; Remans, R.; Fritz, S.; Gerber, J.S.; Nelson, G.; See, L.; Waha, K. Farming and the geography of nutrient production for human use: A transdisciplinary analysis. Lancet Planet. Health 2017, 1, e33-e42. [CrossRef]

45. Teshome, A.; Torrance, J.K.; Baum, B.; Fahrig, L.; Lambert, J.D.H.; Arnason, J.T. Traditional farmers' knowledge of sorghum (Sorghum nicolor, [Poaceae]) landrace storability in Ethiopia. Econ. Bot. 1999, 53, 69-78. [CrossRef]

46. Estrada-Carmona, N.; Attwood, S.; Cole, S.M.; Remans, R.; DeClerck, F. A gendered ecosystem services approach to identify novel and locally-relevant strategies for jointly improving food security, nutrition, and conservation in the barotse floodplain. Int. J. Agric. Sustain. 2020, 18, 351-375. [CrossRef]

47. Galhena, D.H.; Freed, R.; Maredia, K.M. Home gardens: A promising approach to enhance household food security and wellbeing. Agric. Food Secur. 2013, 2, 1-13. [CrossRef]

48. Feliciano, D. A review on the contribution of crop diversification to Sustainable Development Goal 1 "No poverty" in different world regions. Sustain. Dev. 2019, 27, 795-808. [CrossRef] 
49. Villamor, G.B.; Van Noordwijk, M.; Djanibekov, U.; Chiong-Javier, M.E.; Catacutan, D. gender differences in land-use decisions: Shaping multifunctional landscapes? Curr. Opin. Environ. Sustain. 2014, 6, 128-133. [CrossRef]

50. Farnworth, C.R.; Baudron, F.; Andersson, J.A.; Misiko, M.; Badstue, L.; Stirling, C.M. Gender and conservation agriculture in East and Southern Africa: Towards a research agenda. Int. J. Agric. Sustain. 2016, 14, 142-165. [CrossRef]

51. Nelson, A.R.L.E.; Ravichandran, K.; Antony, U. The impact of the green revolution on indigenous crops of India. J. Ethn. Foods 2019, 6, 1-10. [CrossRef]

52. Rana, J.C.; Tyagi, R.K.; Sharma, S.K. On-farm conservation-initiatives by NBPGR in the Western Himalayan Region. Indian J. Plant Genet. Resour. 2010, 23, 122-125.

53. Mandizvo, T.; Odindo, A.O.; Mashilo, J. Citron watermelon potential to improve crop diversification and reduce negative impacts of climate change. Sustainability 2021, 13, 2269. [CrossRef]

54. Jiménez-Ballesta, R.; García-Navarro, F.J.; García-Giménez, R.; Trujillo-González, J.M.; Iñigo, V.; Asensio, C. Agroecological analysis of cucumber (Cucumis Sativus L.) crops in orchards in a Mediterranean environment. J. Agric. Crop. 2018.

55. Genesys. Available online: https:/ / www.genesys-pgr.org (accessed on 25 August 2021). 